\title{
Hong Kong, a reflection...at the Canadian Association of Gastroenterology Hong Kong meeting
}

\author{
HuGH CHAUn, MA, BM, FRCP, FRCPC
}

A S WE APPROACHED HONG KONG HARBOUR IN THE darkness of the night, after a 14 hour, nonstop flight in a Cathay Pacific jumbo jet from Vancouver, the shadows of outlying islands soon gave way to a myriad of glittering lights, as the highrise shoreline of Hong Kong island and the silhouettes of ships below rushed by the plane's window. It recalled the amazing prophesy of a 12 th century Chinese magician-poet called Bai Yue-shan. He had foreseen "a Hong Kong ablaze with a host of stars in the deep night, and ten thousand ships passing to and fro within the harbour". A few moments later, we landed on the runway at Kai Tak, projecting far out into the water, initially invisible, and surrounded by the darkness of the sea on either side. On our way across the harbour to the hotel in Wanchai, the taxi driver lamented at the inevitable fate that awaits 1997.

In the dining room the next morning, Drs Alan Thomson and Richard Hunt were deeply absorbed in planning for the Canadian Association of Gastroenterology's bid to hold the 1994 World Congress in Vancouver. Looking out from our breakfast table, sheltered within the walls of the magnificent New World Harbour View Hotel from the noise outside, we felt a strange air of unreality. Ferries, sampans, junks, barges, tugs and the curious ornate 'Pink Pearl of the Orient' glided

Division of Gastroenterology, Department of Medicine, University Hospital; and University of British Columbia, Vancouver, British Columbia

Correspondence and reprints: Dr Hugh Chaun, Suite 601, 805 West Broadway, Vancouver, British Columbia V5Z IK1. Telephone (604) $872-0717$

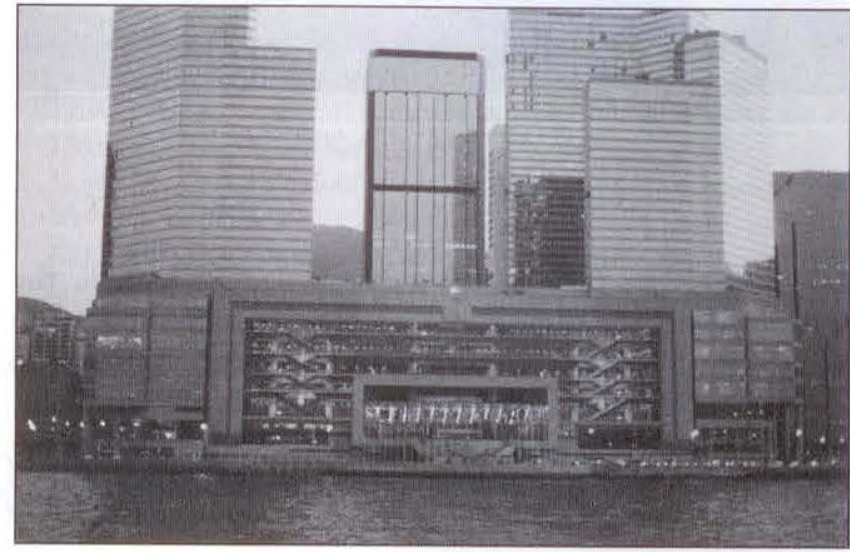

Hong Kong Convention and Exhibition Centre complex, as seen from the harbour

across the serene and apparently tranquil harbour, amidst the fleet of merchant ships lying offshore. A haze hung over the Kowloon peninsula and the hills beyond. Another jumbo jet would vanish behind the buildings, and reappear moments later on the Kai Tak runway.

The Canadian Association of Gastroenterology/Hong Kong Society of Gastroenterology meeting was held predominantly in the new and elegant complex of the Hong Kong Convention and Exhibition Centre, which also includes the New World Harbour View and Grand Hyatt Hotels. It has been built on reclaimed land along the harbourfront in Wanchai. As one looks west from a pedestrian 


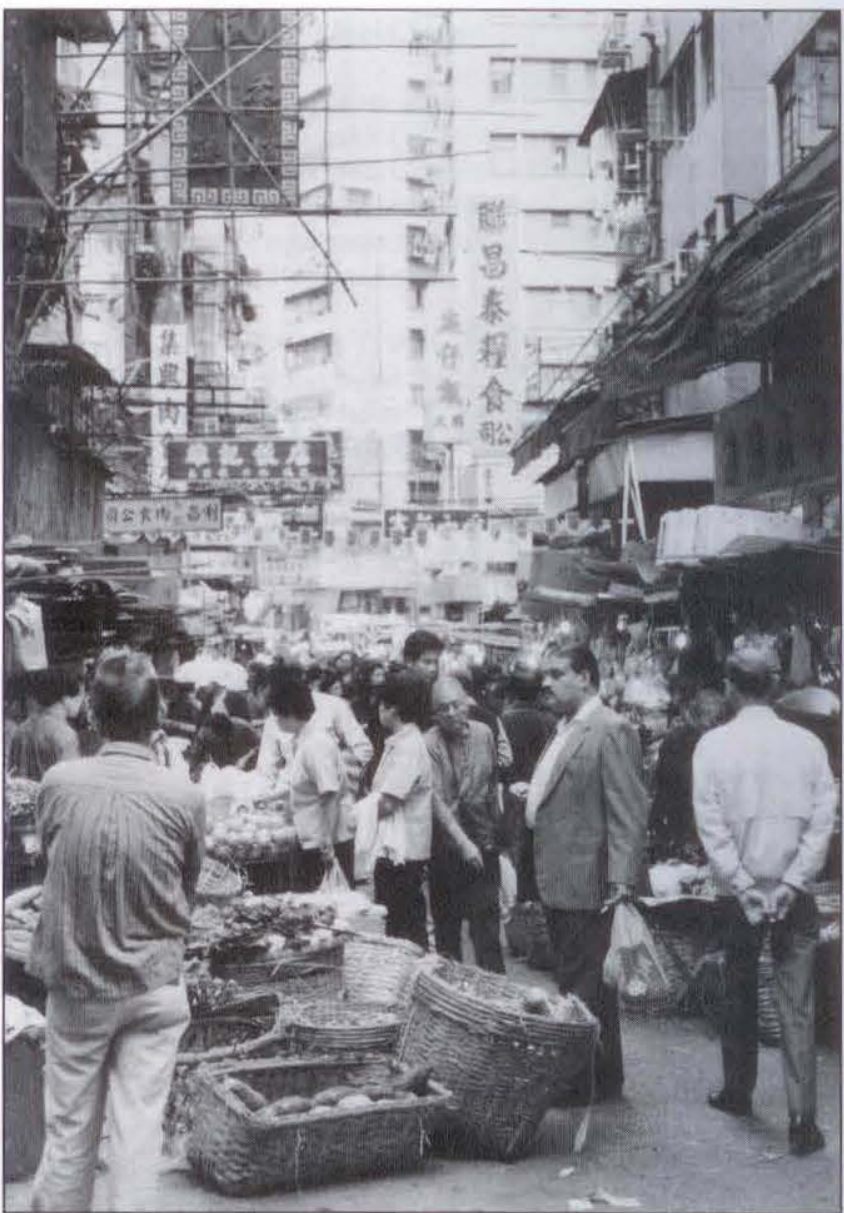

A side street in the old district at Wanchai

bridge near the convention centre towards 'Central', the business district of Hong Kong, the skyscrapers beyond create a transient illusion of a North American city. It was easy to forget that Wanchai had once been The World of Suzie Wong, made famous by Richard Mason's novel, and the home of the China Fleet Club near the old naval dockyard, frequented by generations of Royal Navy men. Suzie Wong's hotel, the Luk Kwok, has been refashioned into a comfortable, reputable hotel. Several streets inland from the waterfront, around Lockhart and Hennessy, Wanchai has retained all of its traditional character. Suspended above the teeming crowds and congested traffic, hundreds of colourful signs fill the air, most displaying large Chinese characters. The spectacle confirms the impression that in this crowded colony, space is at a premium, both at street level and above ground. Among the taller apartment buildings, drying laundry is suspended over bamboo poles projecting from windows at all levels. In the alleys, pedestrians spill over from narrow sidewalks, occupied by stalls displaying their wares: $T$ shirts, jeans, leather goods, various dried food items, fruits and vegetables, jewellery, and electronic gadgets of all kinds.

From my seat at the rear of the bus with Drs Jim Barrowman and Ivan Beck on our way to the Queen Mary Hospital in Pokfulum, I saw modern Hong Kong unfold fleetingly before my eyes. Among the twists and turns of overpasses, skyscraper office buildings and apartment blocks erupt everywhere. It has been said that "only the temporary is permanent in Hong Kong", and few historic buildings remain. The dome of the old Supreme Court of Hong Kong, of 1900 vintage, now the Legislative Council (Legco) building, is no longer a visible landmark of the harbourfront, dwarfed by the commercial structures around it. Queen Victoria's statue, for generations the centrepiece of Statue Square, has long been relocated in Victoria Park at Causeway Bay, possibly inspiring Khursh and Olive Jeejeebhoy to jog there each morning. Hong Kong has been reputed to be governed by the Jockey Club, the Hong Kong \& Shanghai Bank, and the Governor, in that order. Successive buildings of the Hong Kong \& Shanghai Banking Corporation have been located at 1 Queen's Road Central. The second in 1935 was the tallest building of the day between Cairo and San Francisco. Along the road from the latest Hong Kong \& Shanghai Bank built in 1985 rises the new and streamlined Hong Kong headquarters of the Bank of China, 70 stories high. It is the tallest building outside North America, imposingly and perhaps symbolically dominating the view from Government House on the slope of the hill above, and probably spoiling its fung shui. Across the road from the Bank of China, St John's Cathedral stands as another rare relic of the old landmarks.

Modernday Hong Kong is in a state of perpetual motion. The sedan chairs are a part of history, and the few remaining rickshaws outside the Hong Kong Star Ferry terminal are largely a photographer's curiosity. However, the double-decker trams, adorned by lavishly colourful advertisements and forever packed with passengers, survive to another age, a nostalgia and the very last of their kind in the world. Despite the Cross-Harbour Tunnel and the supremely efficient Underground Mass Transit Railway System, the Star Ferries continue to be part of everyday life in the colony, as they have been since 1868. From the Wanchai terminal, it is a 10 minute ride to Kowloon, and the tailors and the world of photographic and computerized merchandise of Tsim Sha Tsui.

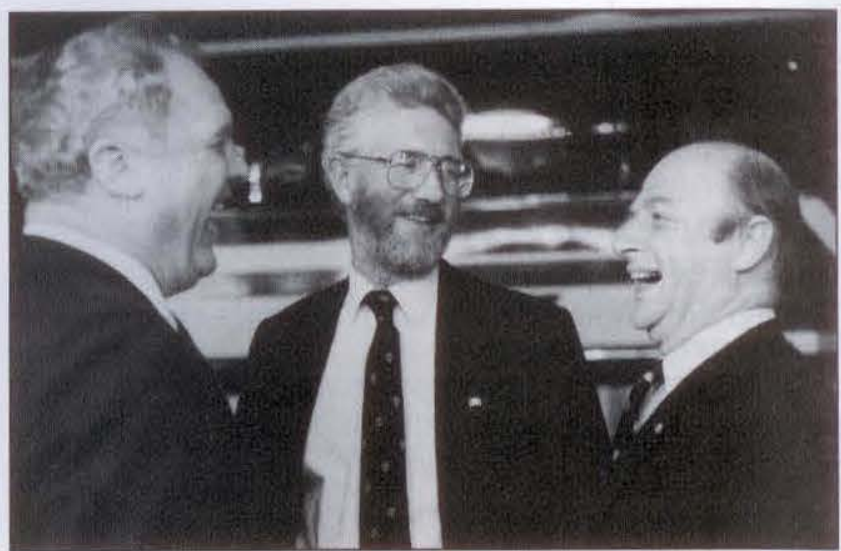

Left to right: Iain Cleator, Giles Stevenson and Richard Hunt in Aberdeen, the home of Hong Kong's floating community of boat people 
The Peak tram has been in operation since 1888 . The first cable railway in Asia, it has a gradient of one in two at its steepest point. In the early days of Hong Kong, the Peak was reached by foot, pony or sedan chair and was, until after the Second World War, reserved exclusively for European residence. Now, it is accessible by a spectacular eight minute ascent up the precipitous hillside in the Peak tram. From atop Victoria Peak, there is a splendid panorama of the harbour, and the 'standing room only' populace below seems a world away. Walking leisurely along the circular path around the Peak, one sees secluded villas here and there partly concealed by shrubberies, and the plethora of sky-reaching buildings below unfold visually between a subtropical growth of trees and shrubs. Beyond the waters off Kennedy Town, hovercrafts jet off towards Macau. On the western side of Hong Kong island at midlevel on the hillside of Pokfulum, the Queen Mary Hospital commands a glorious view of the sea beyond. Along the southern shore stands Aberdeen, the home of Hong Kong's floating community of boat people, families of many generations, and the exotic Jumbo and other floating seafood restaurants. Stanley peninsula is farther along the island's southern shore, and Stanley market is noted for its 'guaranteed bargains'.

Hong Kong had been described in the last century as "one of the unhealthiest places in the British Empire". The colonists were often troubled by disease, and 'toxic emanations' from Chinatown were thought to be a contributory factor. Some said that the island rocks gave out 'pernicious influences'. Malaria and dysentery were endemic, and there were frequent epidemics of typhus and cholera. In the latter part of the 19th century, bubonic plague killed 2500 people in Hong Kong. In 1882, life expectancy was 18 years and four months. Much has changed, and the fearful epidemics have long been checked. Throughout its history,
Hong Kong has had its medical heroes. One was Dr (later Sir) Patrick Manson, tropical medicine physician of world renown, who arrived in the territory in the late 1880s. Appalled by the unsanitary methods of the local residents, he took an active interest in the local milk supply, and was instrumental in the founding of the Dairy Farm Company Limited. Many of the hospitals and clinics in Hong Kong are financed by the Royal Hong Kong Jockey Club or by private enterprise. As striking contrasts are part and parcel of many aspects of life in the colony, so medical care varies in the extreme, from the highest standards of excellence of the Faculty of Medicine at the University, to the services given by unqualified practitioners, many of whom have apparently been beyond the reach of government regulations.

By 1997, Hong Kong will have been in existence for 156 years. It has been miraculously transformed from a barren rock and a British opium port into a world class financial centre of relentless activity and opportunities. It is also a place of extreme contrasts and contradictions. The importance of fung shui and lucky numbers, the bamboo scaffolding, the abacus, the clatter of mah jong and the ever present smell of joss sticks prevail amidst a world as comprehensively computerized as any place on earth. As the realization of 1997 dawns nearer with the passage of another year and another decade, it is hoped that Mao's saying of 1957 will be applicable to a new era of Hong Kong's history: "Let a hundred flowers bloom, let a hundred schools of thought contend..."

\section{REFERENCES}

1. Morris J. Hong Kong. New York: Random House, 1988.

2. Koteff W. In the shadow of China. Physician's Management Manuals 1989;84-94.

3. Fitzpatrick E. Doctor nurses dairy industry from infancy. Sunday Morning Post (Hong Kong) December 18, 1988:16. 


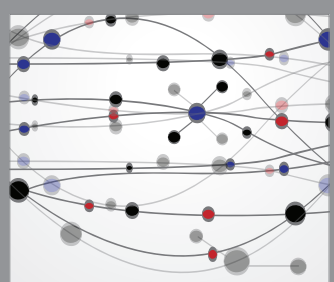

The Scientific World Journal
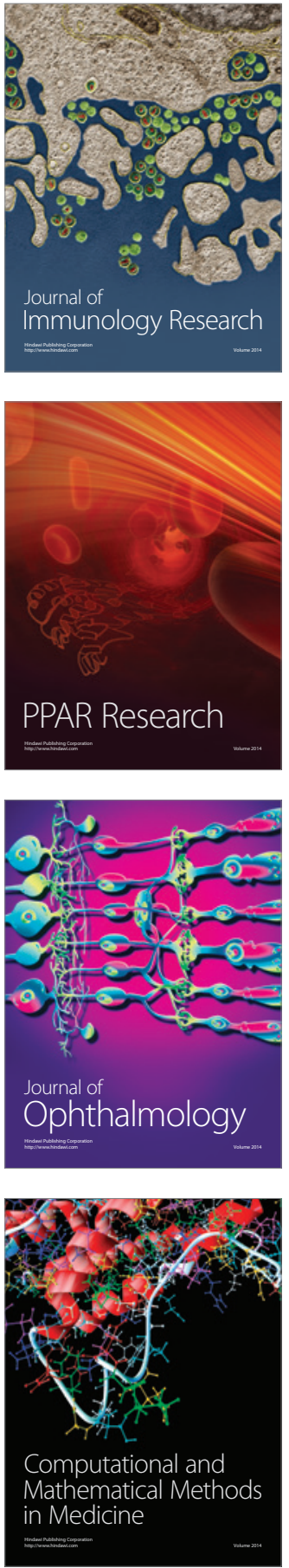

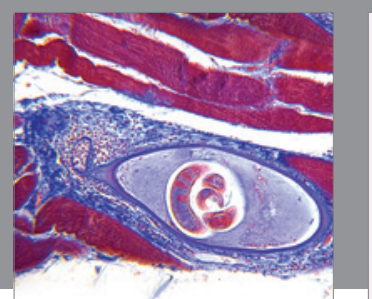

Gastroenterology Research and Practice

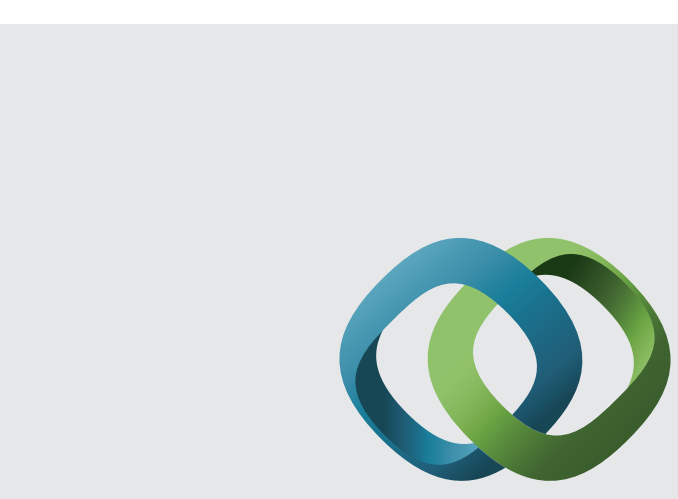

\section{Hindawi}

Submit your manuscripts at

http://www.hindawi.com
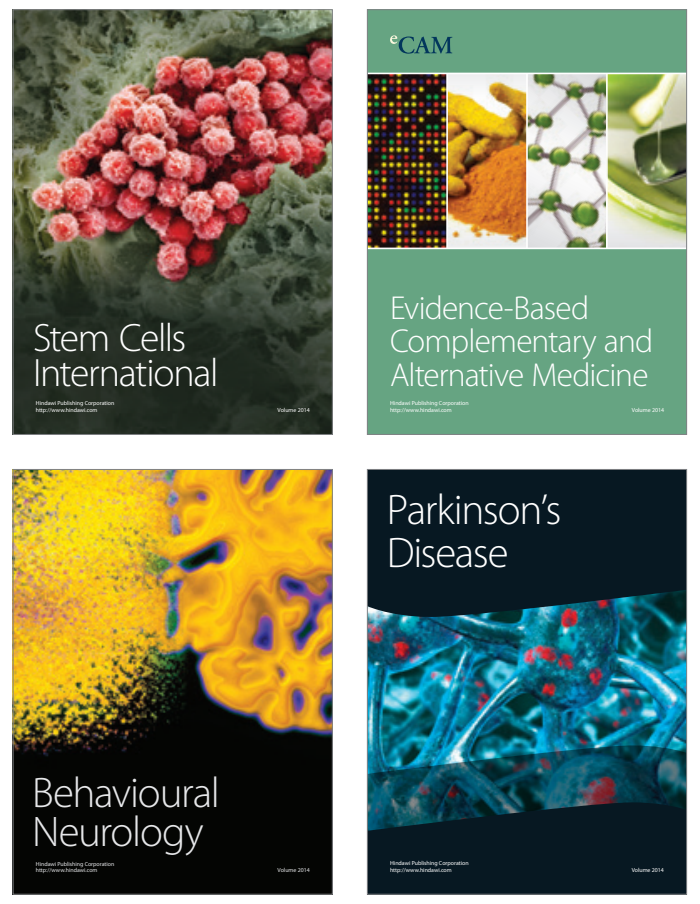
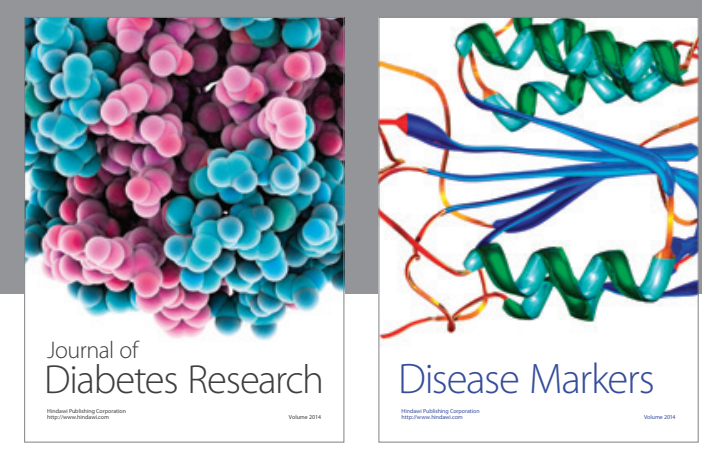

Disease Markers
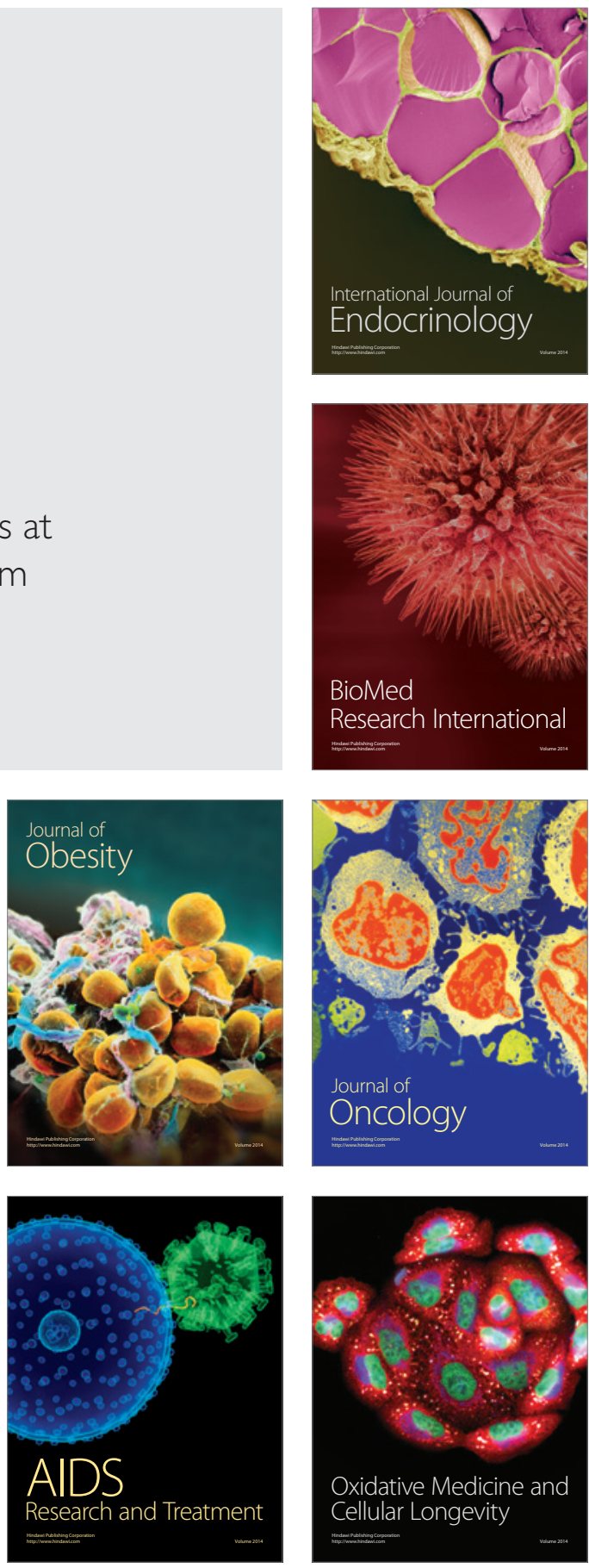